\title{
Photography and the Unseen
}

Christos Lynteris and Rupert Stasch

Introduction to themed section, Visual Anthropology Review 35(1), 2019.

The promise of mechanical and digital visual technologies is often thought to stem from their ability to render visible the invisible, as part of a wider demystification constitutive of modernity. This special issue approaches the key visual technology of photography, with anthropological attention to a still more complex epistemological and ontological process: not just transformation of the unseen into the seen, but also transformation in the very character of the unseen itself, as a social experience.

Recent literature on photographic techniques and practices, in fields including visual studies, history, anthropology, and science and technology studies, has illuminated ways in which the efficacy of photography derives not simply from its power of revealing what is hidden in the world, but equally from its ability to forge new relations with a series of phenomena, events or forms "at the edge of sight," as Shawn Michelle Smith has put it in a particularly valuable study (Smith 2013). Smith's return to what Walter Benjamin, in his Little History of Photography, referred to as the "optical unconscious" has stimulated a new cycle of works and debates (see for example the contributions to Smith and Sliwinski 2017), which promise to enrich, in turn, the interest in Benjamin's notion already long-established among anthropologists (Lynteris and Prince 2016; Mascia-Lees and Sharpe 1994; Pinney 2016; Taussig 1991; Wolbert 2000).

In his now famous essay, Benjamin wrote: 
It is through photography that we first discover the existence of the optical unconscious, just as we discover the instinctual unconscious through psychoanalysis. Details of structure, cellular tissue, with which technology and medicine are normally concerned - all this is, in its origins, more native to the camera than the atmospheric landscape or the soulful portrait. Yet at the same time, photography reveals in this material physiognomic aspects, image worlds, which dwell in the smallest things - meaningful yet covert enough to find a hiding place in waking dreams, but which, enlarged and capable of formulation, make the difference between technology and magic visible as a thoroughly historical variable. (Benjamin 1999 [1931]: 511-512)

Benjamin's idea was based on a pervasive way of perceiving photography at the turn of the century, exemplified by the celebrated example of Muybridge's 1881 images of a running horse. As is well known, Muybridge was commissioned by the railroad magnate and horse breeder Leland Stanford to settle the question of whether at any moment a galloping horse's legs were all in the air. Muybridge's sequence of stills proved this was the case, ushering in a new era in photography's use and perception. On Smith's account, Benjamin read such breakthroughs dialectically as a matter of not only a viewer being made aware "of new visual realms," but also being made aware in new ways "of what one could not and did not see" (Smith 2013: 4). We find anthropologically productive Smith's emphasis on social and cultural dimensions of visual epistemology, in this recuperation of Benjamin's concept (against the background of the influential, anthropologically defensible critique of the psychoanalytic adequacy of Benjamin's concept by Rosalind Krauss 1993). Smith's reading invites us to see photography as a technology that not only reveals an unseen world, but also reveals the world as unseen. Photography does not fully disclose the 
world, "but makes us aware of its invisibility" (Smith 2013: 6), and so "unseat[ing] the fantasy of mastery that surrounds the desire to see and to know" (Smith and Sliwinski 2017: 2). At the same time as photography stabilizes vision by showing and rendering to objectivity what was hitherto imperceptible (Daston and Gallison 2007; Tucker 2013), the medium also amplifies the experience of "imperceptibility" itself, by revealing human interaction with the world as structured around irreducible visual blind spots.

This special issue brings together anthropological work exploring different forms of this dialectic of simultaneous stabilization of vision and expansion of the unseen. Our authors document how photography's generative suspension between invisibility and the unseen shape specific historical and social fields of vision.

Across Smith's own case studies, her use of the term "unseen" is capacious. She has a regular concern with certain photographs' relation to an unseen of racial categories, racial ideologies, and structures of racial domination. Many photographs, too, operate at the edge of an unseen of sexuality, sexual politics, and the sexual body's further ties of mutual figuration with narratives of nation or race. Smith also applies the vocabulary of the unseen to photographers' technical and social processes. And she uses this same language to discuss complex structures of temporal consciousness, such as present people's difficult, not fully visual, relation to a messianic past of Christ's death; to a utopian but lost past of idealized simplicity; or to avoided consciousness of the current world's actual makeup. Also describable as unseen are epistemological structures of photographs and their effects, such as the "promise of photographic evidence" that is by nature "perpetually unfulfilled," or the cognitive inference of motion superadded to Muybridge's juxtaposed stills. ${ }^{1}$ 
The articles collected here likewise explore quite varied levels to how "photography brushes against the unseen" (Smith 2013:8). They do so across a wider range of historical contexts than Smith's mainly U.S.-focused account, though they all begin with photographies of the late nineteenth or early twentieth century. Each article continues and extends a longer-term inquiry its author has pursued, not necessarily oriented by direct debts to Smith or to the many other theorists who since at least Plato have underlined forms of dialectical co-implication between the visible and the more-than-seen. Besides drawing on Benjamin, Smith herself takes inspiration from Mitchell's account of the academic analysis of visuality as a process of becoming aware "that vision is itself invisible; that we cannot see what seeing is," and a process of bringing those invisible, unseen underpinnings of the seen into explicit expression (Mitchell 2005:337,343; see also the exceptional ethnographic development of these ideas by Gursel 2016). Bryson provides another possible touchstone, in a passage referencing the convergence of depicted parallel lines in a well-known Raphael painting:

The viewpoint and the vanishing point are inseparable: there is no viewpoint without vanishing point, and no vanishing point without viewing point. The self-possession of the viewing subject has built into it, therefore, the principle of its own abolition: annihilation of the subject as center is a condition of the very moment of the look. (1988:91)

Bryson goes on to metaphorically expand the "vanishing point" of what is spatially, visually beyond the viewer's sight to encompass the social otherness of other subjects who look, and with the historical, cultural understandings that precede a subject's visual experience. In a slightly different register, Merleau-Ponty observes that "objects form a system in which one cannot show itself without concealing others" 
(2002:78). Or there is Diane Arbus' epigram that “A photograph is a secret about a secret. The more it tells you the less you know." The theme of sight's edge is important and multilayered, surfacing in many modes of expression.

Yet we see a certain value in drawing these articles together in the particular terms of Smith's intervention, especially the renewed attention her framing gives to the systematic relations between seen and unseen aspects of photographic efficacy. Photography's fundamental historical issue tends recurrently to be that the visible, and specifically depictive aspect of photographs is intensely forceful and attentiondrawing, but that at the same time photographs mean and do more than they depict. How does this happen? To study the edge of sight is to investigate this binding and co-creation between depictive and more-than-depictive layers of what images make present, and the articles collected here are rich contributions to such a project.

Roy Dilley offers a meticulous archival recovery of colonial social structures and ideologies unseen or semi-visible in photographs of French officer Henri Gaden in West Africa, and recovery also of complexities of Gaden's own convictions toward the colonial order. For example, at the extra-visual edge of the photographs and their circulation, there is a sexual and racial order of widespread practices of intimacy between French men and African women, acknowledged within West African social space but not to be known in the men's home country. Photographs depicting African women and Frenchmen in the same frame could not circulate in the metropole, because of the thought of possible sexual intimacy triggered by co-presence of the cross-sex, cross-race figures. Dilley reproduces a glass plate image from the Gaden archive depicting three bare-breasted African women and a white-clad colonial officer, with a line across the plate between the man and the women, drawn by authorities preparing a cropped version of the image of the three women alone for publication in 
an official military campaign memoir. To borrow phrasing from Smith (2013:14), this French West African racial order is constituted, in significant part, through "a dynamic of revelation and obfuscation, of hypervisibility and invisibility," including structured ways that "whiteness emerges into and recedes from sight in a wide range of photographs." While Dilley describes how published photographs used the hypervisible, typified blackness of "colourful local human figures and alluring landscapes" to communicate an idea of a very separate whiteness as "clean an clinical military operation in an imagined exotic theatre," his account also traces in Gaden's images a few indications of his reflexivity about the colonial social world, and his distance or disillusionment in relation to the official regime doctrines.

In a similar labor of archival recovery, Elizabeth Edwards investigates a transformative phase in the making of British publics, through the making of popular historical consciousness centered in old buildings stewarded by the Inspectorate of Ancient Monuments. She examines this government agency's project, across three decades from 1910, of promoting a sense of collective ownership of the buildings' remains, through sale of sets of postcards depicting architectural and archaeological features of monastic ruins. Edwards sifts the postcard-related deliberations of civil servants, alongside visual patterns of the extant images, to chart the cultivation of "popular historicality." Notoriously, temporality is both invisible, and immanent to everything seen; consciousness of temporality is more invisible still. Photographic postcards made buildings visible, and encouraged certain ways of looking at their features with appreciation and even 'reverence.' In tracing the visual pedagogies by which British publics were newly encouraged to experience the presence of an otherwise unseen, inaccessible past via buildings, Edwards also traces the unseen of historical consciousness itself, and the new forms of collectivity created through it. 
There are parallels here to Smith's reading of imagery of rustic simplicity in the United States in the photographs of Chansonetta Stanley Emmons from roughly the same era (Smith 2013:139-172). Yet in Edwards' reconstruction of the Inspectorate's activities, arguably the relation between photographic depiction and what is unseen of the past or present is more complex, more banal, and more constitutive (rather than repressive) than in Emmons' project of "nostalgia," as construed by Smith.

Gregory Delaplace develops a bracing model of early ethnographic photographers organizing their practice as a reflexive engagement with sight's edge. These photographers arranged what was seen exactly to invite consciousness of something further, unseen but inferably present. Their backdrops, for example, created a foreground of the supra-visible but intelligible presence of culture, in pointed contrast with the Lamprey grid backdrop of anthropometric photography's ideology that to see is to know, that human difference is entirely there, in the racialized visible body. Delaplace also identifies "spirit photography" as a significant other on ethnographic photography's opposite flank. By the standards of a science of culture, this quest for ghosts finds too much in the photographic unseen, just as anthropometric photography finds too little. Another candidate for this position might be the pictorialist aesthetics that also thrived in the late 19th and early 20 th centuries. As Smith observes about painting-like, soft-focus, compositions of staged scenes like the crucifixion of Christ in photographs of F. Holland Day: "Making images 'thick' with atmosphere, the pictorialists unsettled the transparency of photographic evidence, drawing attention to the filters through which we view the photographed body, including the sharp filters of science" (45). Smith reads the oft-derided aesthetics of pictorialism as a sophisticated invitation for viewers "to see beyond the detail," taking 
what is visible as "a portal to the unseen", even a portal to "messianic moments" (41, $71)$.

Photographic depiction as a path of access to the transcendent is at the core of Liam Buckley's's remarkable account of the long afterlife of five photographs of the Hindu saint Sri Ramakrishna, taken across the years just before his death in 1886. All five images depict Ramakrishna in a state of samadhi: ecstatic, meditative merging of individual consciousness with the divine. The afterlife of the images up to the present has been grounded in Ramakrishna's own spiritual responses to photography, and his incorporation of ideas of photography into his spiritual teachings. Ramakrishna went into the ecstatic state as he was being photographed, and again when he looked at his photographic image. In teachings, he metaphorically modeled the relation between devotee and divinity on photographic chemistry: "A real devotee develops the power of assimilating instruction. An image cannot be impressed on bare glass, but only on glass stained with a black solution, as in photography. The black solution is devotion to God." Concerning a congregation of Ramakrishna worshippers in Mysore today, Buckley describes how copies of the most famous photo of the saint are experienced as his living presence, as in the prescription always to face toward the image, even when moving away, and the understanding that touching photographic light is a path to self-surrender. Worshippers also emphasize the multisensory character of the divine's photographic presence: this presence is felt, tasted, heard, and smelled. Here the "edge of sight" includes visuality's interweaving with other senses, and with a particular model of divinity and human devotion. But sight's edge also dramatically includes a particular definition photographic indexicality itself. Surrounding the visible image, there is an unseen understanding of the kind of contiguity that exists between photograph, depicted subject, and viewers. The profoundly cultural, 
historical character of this unseen and normally naturalized definition stands out, thanks to the unusually rich forms and modes of religious presence that are photographically routinized in such a case (compare Nakassis 2017; Nakassis forthcoming).

Taken together, these articles underline a similar point about the profoundly historical character of the overall dialectics of photographic seen and unseen. In each case elucidated by the authors, the "edge of sight" is an elaborately patterned, even systematic field of relations, but very differently constituted by and between different collectivities, institutions, and individuals.

\section{Acknowledgements}

We thank the Centre for Research in the Arts, Social Sciences and Humanities (CRASSH) at the University of Cambridge for a Faculty Research Group grant making possible the seminar series on Photography between Invisibility and the Unseen (2016-2107) in which the majority of papers in this issue were presented and discussed. We also thank our co-conveners François Penz and Branwyn Poleykett, CRASSH visiting fellow Christopher Ball, and the speakers and participants in the seminar, for their generous contributions to this project.

\section{Notes}

\footnotetext{
${ }^{1}$ For race, see Smith (2013: 14-16, 19, 27-31, 46, 83-86, 100, 135, 219). For sexual politics, see pp. 31-35, 47-69, 86-97, 167, 219. For unseen photographers and production processes, see e.g. 102-103. For the unseen and temporality, see
} 
pp. $139,144,172$. For the "promise of photographic evidence" and other unseen levels of photographic epistemology, see pp. 71, 79-82, 98, 160-163, 200.

\section{References}

Benjamin, Walter. 1999 [1931]. Little History of Photography. From Selected Writings: Volume 2, 1927-1934, pp. 507-530, Cambridge, MA: The Belknap Press of Harvard University Press.

Bryson, Norman. 1988. The Gaze in the Expanded Field. In Vision and Visuality. Dia Art Foundations Discussions in Contemporary Culture, Number 2. Hal Foster, ed. Pp. 87-108. Seattle: Bay Press.

Gursel, Zeynep Devrim. 2016. Image brokers: visualizing world news in the age of digital circulation. Berkeley: University of California Press.

Krauss, Rosalind. The Optical Unconscious. Cambridge, MA: MIT Press, 1993

Lynteris, Christos and Ruth J. Prince. 2016. Anthropology and Medical Photography: Ethnographic, Critical and Comparative Perspectives. Visual Anthropology Special Issue: Medicine, Photography and Anthropology 29(2):101-117.

Mascia-Lees, Frances E., and Patricia Sharpe. 1994. The Anthropological Unconscious. American Anthropologist 96: 649-660.

Merleau-Ponty, Maurice. 2002[1945]. Phenomenology of perception. Colin Smith, transl. London: Routledge.

Mitchell, W. J. T. 2005. What Do Pictures Want?: The Lives and Loves of Images. Chicago: University of Chicago Press.

Nakassis, Constantine. 2017. Rajini's Finger, Indexicality, and the Metapragmatics of Presence. Signs and Society 5(2):201-242. 
. forthcoming. The Hero's Mass and the Ontological Politics of the Image in

Tamil Cinema. Journal of Cinema and Media Studies.

Pinney, Christopher. 2016. Crisis and Visual Critique. Visual Anthropology Review 32(1):73-78.

Smith, Shawn Michelle, and S. Sliwinski. 2017. 'Introduction'. In S. M. Smith and S. Sliwinski (eds) Photography and the Optical Unconscious, pp. 1-31. Durham: Duke University Press.

Smith, Shawn Michelle. 2013. At the Edge of Sight: Photography and the Unseen. Durham, NC: Duke University Press.

Taussig, Miachel T. 1991. Tactility and Distraction. Cultural Anthropology 6(2): 147153.

Tucker, Jennifer J., Nature Exposed: Photography as Eyewitness in Victorian Science. Baltimore: Johns Hopkins University Press, 2013.

Wolbert, Barbara. 2000. The Anthropologist as Photographer: The Visual Construction of Ethnographic Authority. Visual Anthropology 13(4):321-343. 